\title{
OCCURRENCE OF COMPLEMENT-FIXING ANTIBODIES REACTIVE WITH NORMAL TISSUE CONSTITUENTS IN NORMAL AND DISEASE STATES *
}

\author{
By LOUIS H. MUSCHEL, LOIS A. SIMONTON, PATRICIA A. WELLS AND \\ EARL H. FIFE, JR.
}

(From the Dept. of Serology, Division of Communicable Disease, Walter Reed Army Institute
of Research, Walter Reed Army Medical Center, Washington, D. C.)

(Submitted for publication September 27, 1960; accepted November 3, 1960)

Serum substances that react with mammalian tissues, present in individuals with certain acute and chronic diseases, have been the object of several recent reviews (2-4). In addition, complement-fixing substances against human tissue have been demonstrated recently in patients with acute viral infections and systemic lupus erythematosus (5). The question of whether these substances are true antibodies, formed as a result of antigenic stimulation, has often been raised. As far as they have been characterized, they possess the attributes of typical antibodies formed in response to injections of foreign materials: relative specificity, occurrence in the globulin fraction of serum, ability to fix complement, and relative heat stability. It would seem reasonable, therefore, to regard them as antibodies.

The implied detrimental effect of an immunological response to one's own antigens and the subsequent production of tissue antibodies was dramatized by Ehrlich with the expression horror autotoxicus. Yet Kidd and Friedewald (6) have demonstrated the existence of tissue antibodies in the sera of normal rabbits that fix complement with constituents of normal rabbit tissue cells. The present work has considered the incidence of these natural antibodies in other species in addition to the rabbit and their possible reactivity against calf thymus as well as rabbit tissue. In addition, the level of these antibodies in human disease and in animals subjected to various experimental conditions has been determined. Finally, certain properties of tissue antibodies have been investigated.

* A preliminary report of this work was presented at the 1960 meeting of the American Association of Immunologists (1).

\section{MATERIALS AND METHODS}

Antigens. Tissue homogenates were prepared from calf thymus and from rabbit liver as described by Gajdusek (5) for human tissues. The stock antigen preparations used contained about 50 and $100 \mathrm{mg}$ protein per $\mathrm{ml}$, respectively, and were free of detectable DNA (Dische test). For the performance of the test, each antigen was diluted $1: 3,1: 9$, and $1: 27$, and $0.3 \mathrm{ml}$ of these dilutions was used. In each instance this represented $5 \mathrm{mg}$ or less of antigen. None of the preparations was anticomplementary under the conditions of the test, and there was no apparent loss of serologic activity during storage for 4 weeks at $-20^{\circ} \mathrm{C}$.

Hemolytic system. The test procedure was a modification of a precise method developed by the Department of Serology, Walter Reed Army Institute of Research (7). The hemolytic system consisted of a suspension of washed sheep erythrocytes, spectrophotometrically standardized to contain $5 \times 10^{8}$ cells per $\mathrm{ml}$, and sensitized with an optimal concentration of hemolysin. Guinea pig complement was titrated by a precise technique in which the 50 per cent hemolytic unit $\left(\mathrm{C}^{\prime} \mathrm{H}_{30}\right)$ was estimated by a plot of the logarithm of the complement volume against the percentage hemolysis converted to probits. The reagent diluent was $0.15 \mathrm{M}$ salt solution of $\mathrm{pH} 7.3$ to 7.4 containing $\mathrm{Mg}^{++}$and $\mathrm{Ca}^{++}$ions in concentrations optimal for hemolysis buffered with triethanolamine.

Test procedure. Each serum was inactivated for 30 minutes at $56^{\circ} \mathrm{C}$ and serially diluted in the diluent before testing. For the test proper, $0.3 \mathrm{ml}$ of serum, complement containing $5 \mathrm{C}^{\prime} \mathrm{H}_{30}$ units, and diluted antigen were combined and incubated for 16 to 18 hours at $4^{\circ} \mathrm{C}$. After the incubation period, $0.6 \mathrm{ml}$ of sensitized erythrocytes was added, and 30 minutes in the water bath at $37^{\circ} \mathrm{C}$ was allowed for hemolysis. The tests were then read by comparison with color standards simulating different percentages of hemolysis. The titer for any serum was considered as the reciprocal of the highest dilution giving not greater than 50 per cent hemolysis with any of the employed dilutions of antigen.

\section{RESULTS}

Tests with normal sera of different species. The occurrence of complement-fixing (CF) tis- 
TABLE I

The reactivity of sera of different normal animals against tissue antigens

\begin{tabular}{|c|c|c|c|c|c|c|c|}
\hline \multirow[b]{2}{*}{ Species } & \multirow[b]{2}{*}{ Antigen } & \multirow[b]{2}{*}{ No. } & \multicolumn{5}{|c|}{ CF titers (reciprocals) } \\
\hline & & & $\begin{array}{c}\text { Nonre- } \\
\text { active } \\
\text { at } 1: 3\end{array}$ & 3 & 9 & 27 & 81 \\
\hline Man & $\begin{array}{l}\text { Rabbit liver } \\
\text { Calf thymus }\end{array}$ & $\begin{array}{l}68 \\
55\end{array}$ & $\begin{array}{l}18 \\
33\end{array}$ & $\begin{array}{l}37 \\
16\end{array}$ & $\begin{array}{r}12 \\
5\end{array}$ & $\begin{array}{l}1 \\
1\end{array}$ & $\begin{array}{l}\mathbf{0} \\
\mathbf{0}\end{array}$ \\
\hline Chimpanzee & $\begin{array}{l}\text { Rabbit liver } \\
\text { Calf thymus }\end{array}$ & $\begin{array}{l}2 \\
2\end{array}$ & $\begin{array}{l}\mathbf{0} \\
\mathbf{0}\end{array}$ & $\begin{array}{l}0 \\
2\end{array}$ & $\begin{array}{l}2 \\
0\end{array}$ & $\begin{array}{l}\mathbf{0} \\
\mathbf{0}\end{array}$ & $\begin{array}{l}\mathbf{0} \\
\mathbf{0}\end{array}$ \\
\hline Monkey & $\begin{array}{l}\text { Rabbit liver } \\
\text { Calf thymus }\end{array}$ & $\begin{array}{l}2 \\
2\end{array}$ & $\begin{array}{l}\mathbf{0} \\
\mathbf{0}\end{array}$ & $\begin{array}{l}\mathbf{0} \\
\mathbf{0}\end{array}$ & $\begin{array}{l}1 \\
1\end{array}$ & $\begin{array}{l}1 \\
1\end{array}$ & $\begin{array}{l}\mathbf{0} \\
\mathbf{0}\end{array}$ \\
\hline Rabbit & $\begin{array}{l}\text { Rabbit liver } \\
\text { Calf thymus }\end{array}$ & $\begin{array}{r}6 \\
15\end{array}$ & $\begin{array}{l}1 \\
1\end{array}$ & $\begin{array}{l}3 \\
3\end{array}$ & $\begin{array}{l}2 \\
5\end{array}$ & $\begin{array}{l}\mathbf{0} \\
5\end{array}$ & $\begin{array}{l}0 \\
1\end{array}$ \\
\hline Guinea pig & $\begin{array}{l}\text { Rabbit liver } \\
\text { Calf thymus }\end{array}$ & $\begin{array}{l}19 \\
19\end{array}$ & $\begin{array}{l}19 \\
19\end{array}$ & $\begin{array}{l}\mathbf{0} \\
\mathbf{0}\end{array}$ & $\begin{array}{l}\mathbf{0} \\
\mathbf{0}\end{array}$ & $\begin{array}{l}\mathbf{0} \\
\mathbf{0}\end{array}$ & $\begin{array}{l}\mathbf{0} \\
\mathbf{0}\end{array}$ \\
\hline Mouse & $\begin{array}{l}\text { Rabbit liver } \\
\text { Calf thymus }\end{array}$ & $\begin{array}{l}2 \text { pools* } \\
2 \text { pools* }\end{array}$ & $\begin{array}{l}2 \\
2\end{array}$ & $\begin{array}{l}\mathbf{0} \\
\mathbf{0}\end{array}$ & $\begin{array}{l}\mathbf{0} \\
\mathbf{0}\end{array}$ & $\begin{array}{l}\mathbf{0} \\
\mathbf{0}\end{array}$ & $\begin{array}{l}\mathbf{0} \\
\mathbf{0}\end{array}$ \\
\hline Rat & $\begin{array}{l}\text { Rabbit liver } \\
\text { Calf thymus }\end{array}$ & $\begin{array}{l}3 \text { pools* } \\
5 \text { pools* }\end{array}$ & $\begin{array}{l}1 \\
1\end{array}$ & $\begin{array}{l}\mathbf{0} \\
\mathbf{4}\end{array}$ & $\begin{array}{l}2 \\
0\end{array}$ & $\begin{array}{l}\mathbf{0} \\
\mathbf{0}\end{array}$ & $\begin{array}{l}\mathbf{0} \\
\mathbf{0}\end{array}$ \\
\hline
\end{tabular}

* Pools of equal volumes of 5 individual sera.

sue antibodies in the sera of normal rabbits was confirmed. The sera of 19 normal guinea pigs, however, were found to be nonreactive with both rabbit liver and calf thymus. Sera of healthy young male adults, candidates for admission to the United States Military Academy at West Point, were variable in their reactivity. These results, together with those obtained in testing several other animal species, are tabulated in Table I.

Tests with sera of laboratory animals. Rabbits inoculated intratesticularly with Treponema pallidum developed high antibody titers against the cardiolipin antigens used in the serodiagnosis of syphilis, but unlike human patients, showed scarcely any rise in titer against calf thymus or rabbit liver saline extract antigens (Table II). On the other hand, rabbits infected with Trypanosoma gambiense or $T$. rhodesiense developed significant antibody increases against saline extract antigens, but essentially no rise in Wassermann
TABLE II

Response of a rabbit to inoculation with $T$. pallidum

\begin{tabular}{lcc}
\hline \multicolumn{1}{c}{ Serum } & $\begin{array}{c}\text { Wassermann anti- } \\
\text { body (cardiolipin } \\
\text { microflocculation) } \\
\text { titer (reciprocal) }\end{array}$ & $\begin{array}{c}\text { CF titer } \\
\text { (reciprocal) } \\
\text { against } \\
\text { calf thymus }\end{array}$ \\
\hline Preinoculation & Nonreactive & 27 \\
Day, postinoculation & & \\
5 & 2 & 27 \\
10 & 64 & 27 \\
17 & 64 & 27 \\
24 & 32 & 27 \\
31 & 8 & 27 \\
45 & 16 & 27 \\
\hline
\end{tabular}

antibody (Table III). One notes in Table III a 27 -fold rise in titer against rabbit liver and at least a 3-fold rise against calf thymus. The decline in $\mathrm{C}^{\prime}$ level from 34 to 19 may be related to the development of tissue antibody and consequent in vivo fixation by antigen-antibody complex, but the titer of 40 on the thirteenth postinoculation day is not easily explained.

The development of tissue antibodies does not by any means, however, invariably follow microbial infection or the injection of microbial products. Guinea pigs infected with lethal doses of the Bitterroot strain of Rocky Mountain spotted fever, carbon tetrachloride-treated guinea pigs infected with Shigella organisms, and chimpanzees orally infected with Salmonella typhosa have not developed elevated levels of these antibodies. Animals: subjected to other experimental conditions also did not develop elevated levels of tissue antibodies. These included severely burned rats, guinea pigs. subjected to $X$-irradiation ( $400 \mathrm{r}$ ), mice subjected to X-irradiation (600 r), and rabbits injected three times with a solution containing poliomyelitis, epidemic and endemic typhus vaccines or tetanus-diphtheria toxoids, plague, and typhoid. and paratyphoid $A$ and $B$ vaccines.

TABLE III

Response of rabbit to inoculation with $T$. gambiense

\begin{tabular}{|c|c|c|c|c|}
\hline Serum & $\begin{array}{l}\text { CF titer } \\
\text { (reciprocal) } \\
\text { against calf } \\
\text { thymus }\end{array}$ & $\begin{array}{c}\text { CF titer } \\
\text { (reciprocal) } \\
\text { against rabbit } \\
\text { liver }\end{array}$ & $\begin{array}{c}C^{C^{\prime} \text { titer }} \\
\left(\mathrm{C}^{\prime} \mathrm{H}_{\mathrm{b} 0} / \mathrm{ml}\right) *\end{array}$ & $\begin{array}{l}\text { Cardiolipin } \\
\text { microflocculation }\end{array}$ \\
\hline \multirow{2}{*}{$\begin{array}{l}\text { Preinoc. } \\
\text { Day, postinoc. } \\
13 \\
28\end{array}$} & 27 & 3 & 34 & Nonreactive \\
\hline & $\begin{array}{l}81 \text { or }> \\
81\end{array}$ & $\begin{array}{l}81 \\
81\end{array}$ & $\begin{array}{l}40 \\
19\end{array}$ & $\begin{array}{l}\text { Nonreactive } \\
\text { Trace reaction } \\
\quad(\text { titer }<1)\end{array}$ \\
\hline
\end{tabular}

* Represents complement titer in $50 \%$ hemolytic units per $\mathrm{ml}$ of serum. 
TABLE IV

Comparison of titers (reciprocals) of 20 sera of patients with rheumatoid arthritis in the bentonite flocculation test and in the complement fixation procedure against calf thymus

\begin{tabular}{cccccc}
\hline \hline & & \multicolumn{4}{c}{ CF against calf thymus } \\
\cline { 3 - 6 } $\begin{array}{c}\text { Bentonite } \\
\text { focculation } \\
\text { titer }\end{array}$ & $\begin{array}{c}\text { No. of } \\
\text { sera } \\
\text { tested }\end{array}$ & $\begin{array}{c}\text { Nonreactive } \\
\text { at } \mathbf{1 : 3}\end{array}$ & 3 & 9 & 27 \\
\hline 16 & 2 & 1 & 1 & 0 & 0 \\
32 & 3 & 3 & 0 & 0 & 0 \\
64 & 3 & 1 & 2 & 0 & 0 \\
128 & 2 & 2 & 0 & 0 & 0 \\
256 or $>$ & 13 & 9 & 1 & 3 & 0 \\
Total & 23 & 16 & 4 & 3 & 0 \\
\hline
\end{tabular}

Tests with human sera; connective tissue diseases. Sera which were reactive in the bentonite flocculation test (8) for rheumatoid factor, from patients with rheumatoid arthritis, were tested with calf thymus antigen in $\mathrm{CF}$ tests. The results given in Table IV indicate that the majority of sera (13 out of 20) from such patients do not have detectable tissue antibody levels, irrespective of rheumatoid factor levels. As was observed in Table I, similar results were obtained with sera from normal healthy individuals. A smaller number of the rheumatoid arthritic sera similarly tested against rabbit liver were mostly nonreactive. Whereas sera of patients with rheumatoid arthritis generally failed to react with tissue antigens, 32 of 33 sera from patients with systemic lupus erythematosus reacted against the calf thymus antigen and to a much higher average titer; the single exception was a patient in a state of remission (Table V). Sixteen of these sera were also tested against rabbit liver and in general yielded comparable but higher titers than those obtained in parallel tests with calf thymus antigen.

Lues and biological false positive (BFP) reactors. An appreciable percentage of sera from patients with luetic infection, verified by clinical status and positive treponemal immobilization tests, reacted against both tissue antigens at ele-

TABLE V

Complement fixation titers (reciprocals) against calf thymus of 33 sera of patients with systemic lupus erythematosus

\begin{tabular}{cccccc}
\hline \hline \multirow{2}{*}{$\begin{array}{c}\text { Total } \\
\text { no. } \\
\text { tested }\end{array}$} & $\begin{array}{c}\text { Nonreactive } \\
\text { at } 1: 3\end{array}$ & 3 & \multicolumn{3}{c}{ CF titers } \\
\cline { 3 - 5 } \cline { 3 - 5 } & 1 & 8 & 7 & 17
\end{tabular}

TABLE VI

Comparison of titers (reciprocals) of Wassermann antibody obtained with the cardiolipin microflocculation test and of complement-fixing antibodies against rabbit liver in 26 sera of luetic patients

\begin{tabular}{cccccc}
\hline \hline & & \multicolumn{4}{c}{ CF against rabbit liver } \\
\cline { 3 - 6 } $\begin{array}{c}\text { Micro- } \\
\text { flocculation } \\
\text { titers }\end{array}$ & $\begin{array}{c}\text { No. } \\
\text { tested }\end{array}$ & $\begin{array}{c}\text { Nonreactive } \\
\text { at 1:3 }\end{array}$ & 3 & 9 & 27 \\
\hline$<1$ & 2 & 1 & 1 & 0 & 0 \\
1 & 5 & 2 & 1 & 2 & 0 \\
2 & 4 & 2 & 2 & 0 & 0 \\
4 & 1 & 1 & 0 & 0 & 0 \\
8 & 2 & 1 & 1 & 0 & 0 \\
16 & 3 & 0 & 1 & 2 & 0 \\
32 or $>$ & 9 & 0 & 1 & 4 & 4 \\
\hline
\end{tabular}

vated levels. Twelve of 26 sera, for example, from the luetic patients reacted with titers of $1: 9$ or greater against rabbit liver. An association was observed, moreover, between the Wassermann antibody titer given in the cardiolipin microflocculation test of the United States Army (9) and the complement-fixation titers against rabbit liver (Table VI). In addition, tests against calf thymus were performed with eight of the sera; three of these specimens gave slide flocculation titers of 32 or greater, and among these were the only two sera with elevated levels of complement-fixing antibodies against calf thymus. Wassermann antibody was shown not to be identical with rabbit liver and calf thymus tissue antibodies, however, by absorption experiments. Absorption of Wassermann antibody from luetic sera by cardiolipin floccules resulted in relatively slight losses of the tissue antibodies. In contrast to the association

TABLE VII

Comparison of titers (reciprocals) for Wassermann antibody with the cardiolipin microflocculation test and calf thymus antibodies in sera of individuals with biological false positive reactions of lues

\begin{tabular}{|c|c|c|c|c|c|}
\hline \multirow[b]{2}{*}{$\begin{array}{c}\text { Cardiolipin } \\
\text { microflocculation }\end{array}$} & \multirow[b]{2}{*}{$\begin{array}{l}\text { No. } \\
\text { tested }\end{array}$} & \multicolumn{4}{|c|}{ Titer against calf thymus } \\
\hline & & $\begin{array}{l}\text { Nonre- } \\
\text { active } \\
\text { at } 1: 3\end{array}$ & 3 & 9 & 27 or $>$ \\
\hline $\begin{array}{l}\text { Weak reaction } \\
\text { titer }<1\end{array}$ & 23 & 9 & 11 & 1 & 2 \\
\hline $\begin{array}{cr}\text { Reaction } & \\
\text { titer } & 1 \\
& 2 \\
& 4 \\
& 8 \\
& 16 \\
& 32\end{array}$ & $\begin{array}{r}24 \\
11 \\
5 \\
5 \\
2 \\
1\end{array}$ & $\begin{array}{r}12 \\
6 \\
1 \\
2 \\
0 \\
0\end{array}$ & $\begin{array}{l}7 \\
3 \\
1 \\
1 \\
1 \\
0\end{array}$ & $\begin{array}{l}2 \\
0 \\
0 \\
2 \\
0 \\
1\end{array}$ & $\begin{array}{l}3 \\
2 \\
3 \\
0 \\
1 \\
0\end{array}$ \\
\hline Total & 71 & 30 & 24 & 6 & 11 \\
\hline
\end{tabular}


TABLE VIII

Tissue antibody levels in a patient with Rocky Mountain spotted fever complicated by a paracolon infection

\begin{tabular}{ccc}
\hline \hline $\begin{array}{c}\text { Days after } \\
\text { onset of } \\
\text { illness* }\end{array}$ & $\begin{array}{c}\text { CF titers } \\
\text { (reciprocals) } \\
\text { against rabbit } \\
\text { liver }\end{array}$ & $\begin{array}{c}\text { CF titers } \\
\text { (reciprocals) } \\
\text { against calf } \\
\text { thymus }\end{array}$ \\
\hline 4 & Neg. at $1: 3$ & Neg. at $1: 3$ \\
13 & 9 & 9 \\
20 & 27 or $>$ & 27 \\
50 & 9 & 3 \\
\hline
\end{tabular}

* Expired on Day 58.

observed between the Wassermann and tissue antibody levels with the sera of luetic patients, the sera of 71 individuals exhibiting BFP reactionsi.e., reactive for Wassermann antibody but nonreactive in the treponemal immobilization test and without clinical evidence or a history indicative of syphilis-did not reveal a similar correlation. The most extensive testing of these sera was performed with calf thymus antigen; the findings are summarized in Table VII. The lack of correlation is observed readily, for example, with the 11 sera giving a titer of 27 or greater against calf thymus in which the cardiolipin microflocculation titers ranged from less than 1 to 16 . Entirely comparable results were obtained with 50 of these sera tested similarly against rabbit liver antigen.

Other infectious diseases. Sera from 15 human cases of poliomyelitis, 8 cases of mumps, and 8 cases of pericarditis of unknown etiology, obtained at various disease stages, were nonreactive or within normal levels with both antigens. However, in a patient with Rocky Mountain spotted fever complicated by paracolon infection, a marked rise and decline, prior to his death, occurred in tissue antibody levels during course of the disease (Table VIII).

Hypocomplementemia. Apparently unrelated to any disease process, slightly elevated tissue antibody levels (titer 1:9 against calf thymus, and $1: 9$ or greater against rabbit liver) have been found in a healthy individual who had had extremely low levels of hemolytic complement for several years (10). The complement level in this individual was about one-tenth that of normal, and the deficiency was in the second component.

Antibody characteristics. The question was raised as to whether the tissue antibodies in patients with connective tissue diseases and in animals with trypanosomal infection were similar to those found in normal humans and rabbits. Kidd and Friedewald (6) observed that essentially all of the antigen in rabbit liver reactive with normal rabbit serum was sedimented at $30,000 \mathrm{rpm}$, comparatively little or none of it remaining in the supernatant fluids. Similar findings were ob-

TABLE IX

Reactions of different sera with centrifuged extracts of normal rabbit liver *

\begin{tabular}{|c|c|c|c|c|c|c|c|}
\hline \multirow[b]{2}{*}{ Serum } & \multirow[b]{2}{*}{ Antigen } & \multicolumn{5}{|c|}{ Antigen dilution } & \multirow[b]{2}{*}{$1: 218$} \\
\hline & & $1: 9 \dagger$ & $1: 27$ & $1: 81$ & $1: 243$ & $1: 729$ & \\
\hline Normal rabbit $121757-2,1: 3$ diln. & $\begin{array}{l}\text { Whole extract } \\
\text { Supernatant } \\
\text { Sediment }\end{array}$ & $\begin{array}{r}20 \\
15 \\
5\end{array}$ & $\begin{array}{r}0 \\
10 \\
0\end{array}$ & $\begin{array}{r}0 \\
60 \\
0\end{array}$ & $\begin{array}{r}0 \\
85 \\
0\end{array}$ & $\begin{array}{r}0 \\
100 \\
10\end{array}$ & $\begin{array}{r}15 \\
100 \\
35\end{array}$ \\
\hline Normal human 30960-7, 1:3 diln. & $\begin{array}{l}\text { Whole extract } \\
\text { Supernatant } \\
\text { Sediment }\end{array}$ & $\begin{array}{r}45 \\
100 \\
20\end{array}$ & $\begin{array}{r}90 \\
100 \\
85\end{array}$ & $\begin{array}{l}100 \\
100 \\
100\end{array}$ & $\begin{array}{l}100 \\
100 \\
100\end{array}$ & $\begin{array}{l}100 \\
100 \\
100\end{array}$ & $\begin{array}{l}100 \\
100 \\
100\end{array}$ \\
\hline Human lupus erythematosus $\ddagger 22960-1,1: 9$ diln. & $\begin{array}{l}\text { Whole extract } \\
\text { Supernatant } \\
\text { Sediment }\end{array}$ & $\begin{array}{r}10 \\
10 \\
0\end{array}$ & $\begin{array}{r}0 \\
20 \\
0\end{array}$ & $\begin{array}{r}0 \\
100 \\
35\end{array}$ & $\begin{array}{r}95 \\
100 \\
95\end{array}$ & $\begin{array}{l}100 \\
100 \\
100\end{array}$ & $\begin{array}{l}100 \\
100 \\
100\end{array}$ \\
\hline Rocky Mountain spotted fever patient, 82659-1 & $\begin{array}{l}\text { Whole extract } \\
\text { Supernatant } \\
\text { Sediment }\end{array}$ & $\begin{array}{r}20 \\
20 \\
0\end{array}$ & $\begin{array}{r}0 \\
20 \\
0\end{array}$ & $\begin{array}{r}0 \\
100 \\
0\end{array}$ & $\begin{array}{r}30 \\
100 \\
40\end{array}$ & $\begin{array}{l}100 \\
100 \\
100\end{array}$ & $\begin{array}{l}100 \\
100 \\
100\end{array}$ \\
\hline Rabbit anti- $T$. gambiense, 11558-2 & $\begin{array}{l}\text { Whole extract } \\
\text { Supernatant } \\
\text { Sediment }\end{array}$ & $\begin{array}{r}15 \\
10 \\
5\end{array}$ & $\begin{array}{l}0 \\
0 \\
0\end{array}$ & $\begin{array}{r}0 \\
80 \\
0\end{array}$ & $\begin{array}{r}0 \\
100 \\
0\end{array}$ & $\begin{array}{r}5 \\
100 \\
15\end{array}$ & $\begin{array}{r}60 \\
100 \\
60\end{array}$ \\
\hline
\end{tabular}

* For the preparation of the extracts, the whole extract was centrifuged at $100,000 \mathrm{G}$ for 1 hour. The sediment was suspended with saline to the original volume of the extract. The numbers represent percentages of hemolysis.

$\dagger$ With the exception of the reactions with serum 30960-7, the lack of complete fixation with the 1:9 antigen dilution probably was caused by an antigen prozone.

‡ Two other sera of patients with lupus erythematosus reacted similarly. 
TABLE $\mathrm{X}$

The heat lability of tissue antibodies against rabbit liver in normal and pathological sera

\begin{tabular}{clc}
\hline \hline \multicolumn{1}{c}{ Serum,${ }^{\circ} \mathrm{C}^{*}$} & & CF titers (reciprocals) \\
\hline 60 & Normal rabbit & 9 \\
65 & Normal rabbit & 3 \\
60 & Rabbit anti- $T$. gambiense & 81 or $>$ \\
65 & Rabbit anti- $T$. gambiense & 9 \\
56 & Normal human & 3 \\
65 & Normal human & Nonreactive at $1: 3$ dilution \\
56 & Human lupus erythematosus & 81 \\
65 & Human lupus erythematosus & 9 \\
56 & Human Rocky Mountain spotted fever & 2.7 \\
65 & Human Rocky Mountain spotted fever & 9
\end{tabular}

* Prior to testing, all sera were heated at the temperatures indicated for 30 minutes. Rabbit sera are ordinarily heated at $60^{\circ}$ instead of $56^{\circ}$ to minimize their anticomplementary properties.

served in testing certain human sera, including sera from normal individuals, several patients with systemic lupus erythematosus, and one with Rocky Mountain spotted fever (Table IX). The heat lability of normal rabbit tissue antibody was paralleled also by these human sera (Table X).

\section{DISCUSSION}

The existence of natural antibodies in rabbits (6) that react in vitro with constituents of normal rabbit tissue cells has been confirmed by the findings in this study. Like other so-called natural antibodies, the incidence of normal tissue antibodies depends upon the species. All of the guinea pig and mouse sera examined were nonreactive against either rabbit liver or calf thymus. In man, on the other hand, a rather high incidence of antibodies against these antigens was found: 74 per cent of sera of normal individuals was reactive against rabbit liver and 40 per cent against calf thymus. A higher incidence of reactivity and higher mean titers were found with the rabbit sera.

Certain characteristics of the tissue antibodies of both the natural and the "acquired" variety, found in the sera of humans with systemic lupus erythematosus and in the sera of humans and animals with infecting diseases, are very similar. They have comparable heat stabilities, and both types react with the relatively easily sedimentable constituents of the tissue extracts. In view of the possible similarity of normal tissue antibodies and those tissue antibodies present at elevated levels in sera of certain patients, it follows that the proc- esses leading to normal levels of tissue antibodies may be accentuated for unknown reasons in certain patients, or conceivably, but less likely, that the elimination of these antibodies is delayed in those patients. The origin of these tissue antibodies has intrigued immunologists for a long time. Their existence is even more puzzling today because of very extensive investigations which have placed the principle of immunological tolerance on a firm basis. According to this principle, if a foreign antigen is introduced into an animal sufficiently early, the antibody-synthesizing mechanism will accept its persistence or later introductions of it without antibody response. Thus, the peculiar mystery of the origin of tissue antibody arises from the presence of tissue antigens as early as conception. Despite this theoretical objection to their presence, two distinct mechanisms have been postulated to account for the formation of tissue antibodies. In the first of these, normal tissue cells are assumed to be injured and altered by harmful agents and thereby rendered antigenic. Microbial agents, cold, heat, and X-rays have been postulated as irritants for the conversion of normal tissue constituents into antigens (11). Our results have failed, however, to demonstrate the occurrence of such a process in experimental animals subjected to extensive burns or X-rays, but have shown its occurrence as a result of microbial invasion. The resulting reaction of a host to its own tissues has been termed autosensitization. Although the antigens used in the present study were usually not derived from the species whose serum was being studied, comparable results with homologous antigens have been ob- 
tained in studies reported by others (12) and in other studies of our own. In our experience, most reactive human sera have shown a similar spectrum of activity with antigens derived from human, rabbit, and bovine livers. Thus, species specificity seems not to be generally involved. Organ specificity is likewise apparently lacking and tissue antibodies are generally capable of reacting with liver, kidney, and thymus. Thus, similar antigenic determinants seem to be predominantly involved in the serological reactivity of tissue extracts, although different tissues are undoubtedly not antigenically identical. Organ specific antibodies have been reported in patients with thyroiditis (13) and pancreatitis (14). The second possibility is that the antigenic components of a microbial agent may give rise to the formation of antibodies cross reactive with tissue constituents. This latter process, designated heterosensitization, has been invoked recently in attempts to explain the presence of deoxyribonucleoprotein antibodies in patients with systemic lupus erythematosus. These antibodies are lacking in species specificity and, conceivably, bacterial or viral nucleoprotein may provide the antigenic stimulus. Similarly, it has been suggested that the presence of tissue precipitins in patients having ulcerative colitis may result from antigenic stimuli provided by the great number of microorganisms known to invade the tissue in this disease (15).

Whatever their origin, tissue antibodies have been found in normal animals and humans. Elevated levels of these antibodies have been found not only in human patients, but also in apparently normal healthy individuals. When these elevated levels exist, they are most apt to occur in individuals who give a biological false positive test for lues (cf. Tables I and VII) but bear no relationship, however, to the Wassermann antibody level. In the present studies, elevated levels of these tissue antibodies occurred in several apparently healthy individuals, which suggests that they may not be directly involved in the pathology of the so-called autoimmune diseases, or that additional conditions are essential. This point of view is corroborated by the findings of other investigators that indicate a poor correlation of the serological findings and tissue damage in experimental thyroiditis (13), experimental al- lergic encephalomyelitis (16) and experimental allergic testicular damage (17). Future work to determine the extent of correlation of tissue antibodies-circulating or possibly absorbed-with pathological changes in disease processes would be most useful. It is not unlikely that tissue damage may be produced either by antibodies which are absorbed by tissue cells and are, therefore, not present in the circulation, or by immunologically altered cells without the mediation of antibody. With respect to the first possibility it is known, for example, in certain particularly severe cases of erythroblastosis fetalis involving $R h$ antibody sensitization, that the circulating antibody levels in the mother rise markedly subsequent to delivery (18). The most plausible explanation for this finding is that the fetus may absorb antibody during gestation. The second possibility involving altered cells invokes an analogy with delayed hypersensitivity, but little evidence to support this thesis is currently available (19).

Tissue antibodies, at elevated levels, were invariably found in cases of systemic lupus erythematosus (SLE). Since the antigens used in the tests contained no detectable DNA, the question may be raised as to whether SLE sera react with cytoplasmic as well as with nuclear material. Other investigators $(12,20)$ have found that SLE sera react with isolated cytoplasmic constituents. It is well established, however, that cell nuclei contain appreciable quantities of non-nucleoprotein antigens soluble in $0.15 \mathrm{M}$ sodium chloride (21) and highly reactive in complement-fixation tests with SLE sera (22). The antigens in this study contain such proteins and it is possible that the SLE and other sera reacted with both nuclear and cytoplasmic substances.

In contrast to the presence of tissue antibodies in patients with SLE, these antibodies were absent in cases of rheumatoid arthritis (Table VI). This result, together with concurrent findings of low levels of hemolytic complement in systemic lupus erythematosus patients and slightly elevated levels in rheumatoid arthritis patients (23) seems to cast doubt upon the assumption of common etiological mechanisms in these two clinical entities. If rheumatoid arthritis is associated with an autoimmune response, then the antibodies do not result in lowered complement levels. 
Complement-fixing antibodies against $\gamma$-globulin in sera of patients with high titers of the rheumatoid factor have not been demonstrated in our laboratory. These findings do not support the premise that the rheumatoid factor is a typical antibody.

The tests with sera from patients with luetic infections have indicated a correlation of Wassermann antibody levels and tissue antibody levels. On the other hand, individuals who produce Wassermann antibody in the absence of luetic infections, so-called biological false positive reactors, often possess markedly elevated levels of tissue antibody (17 of the 71 had titers of 9 or greater against calf thymus, as indicated in Table VII), but these bore no relationship to the Wassermann antibody titer. The presence of Wassermann antibody in these reactors has been regarded as a sign of overt or latent immunological disease (24). Since systemic lupus erythematosus is the immunological disease par excellence and since practically all patients suffering from it have elevated levels of tissue homogenate antibody, but not necessarily of Wassermann antibody, it may well be that tissue homogenate antigen may provide serological evidence of greater validity for autoimmune disease processes than does Wassermann antigen.

With respect to the relation of infectious diseases and the development of tissue antibodies, humans with mumps or poliomyelitis, guinea pigs with Rocky Mountain spotted fever, and chimpanzees with typhoid fever all failed to show enhanced tissue antibody levels; a notable exception was a human with a fatal concurrent rickettsial and bacterial infection who developed high levels of tissue antibodies. A very recent study has indicated also that human patients with bacterial infection do not generally develop elevated levels of tissue antibodies (25). Rabbits inoculated intratesticularly with $T$. pallidum developed high Wassermann antibody titers but, unlike human patients with syphilis, developed only a very slight rise in titer against the antigens used in this study. This difference in serological response between humans and the rabbit may be related to the fact that experimental syphilis in the rabbit results chiefly in lesions of the skin, bones, and the eyes, but visceral lesions are virtually unknown (26). On the other hand, rab- bits infected with $T$. gambiense or $T$. rhodesiense developed significant antibody increases against tissue homogenates but scarcely any rise in Wassermann antibody. It appears then that the autoantigens induced by trypanosomal infection in the rabbit are qualitatively different from those induced by treponemal infection.

In addition to the lack of enhanced tissue antibody levels in many patients with infectious diseases, the failure to find increased tissue antibody levels in experimental animals subjected to burns, X-irradiation, and large amounts of vaccines indicates that tissue damage per se does not lead to the appearance of tissue antibodies, but rather that the tissue changes leading to autoantigenicity are rather limited and possibly of a unique nature. The significance of the association, if any, in one patient between an extremely low level of complement and slightly elevated levels of tissue antibody levels is not readily apparent. In this individual as with other patients, the antibodies and complement measured in the circulation probably represent only one phase of a very complex and dynamic situation involving tissue alteration resulting in autoantigenicity, synthesis of antibodies, absorption of antibodies and complement fixation, and degradation or elimination of antibodies influenced by hormones and other factors.

\section{SUM MARY}

Normal sera of several animal species possess tissue antibodies demonstrable by complement fixation with calf thymus or rabbit liver homogenates. Enhanced levels of these antibodies have been found in patients with systemic lupus erythematosus and lues, and in animals experimentally infected with trypanosomes. They have not been observed in patients having rheumatoid arthritis or many infectious diseases, or in animals subjected to a wide variety of conditions. Coincidentally, the results have suggested that antibody levels against tissue homogenates may afford a more reliable index of overt or incipient autoimmune disease than does Wassermann antibody. Finally, the presence of these tissue antibodies in high titer in apparently normal healthy individuals lends additional credence to the concept that autoantibodies are not exclusively involved 
in the pathological findings of the so-called autoimmune diseases.

\section{ACKNOWLEDGMENT}

Valuable contributions of sera of chimpanzees infected with $S$. typhosa were provided by Lt. Colonel Sidney Gaines, MSC; guinea pigs with experimental shigellosis by Dr. Samuel Formal; guinea pigs infected with the rickettsial agent of Rocky Mountain spotted fever by Miss Marilyn Bozeman; and burned rats by Dr. Ole Malm.

\section{REFERENCES}

1. Muschel, L. H., Simonton, L. A., and Wells, P. A. Tissue antibody studies. Fed. Proc. 1960, 19, 202.

2. Raffel, S. Immunologic disease. Pediatrics 1958, 21, 849.

3. Grabar, P., and Miescher, P., Eds. Immunopathology. First Internat. Symp. Basel/Stuttgart, Benno, Schwabe, 1959.

4. Clough, P. W. Auto-immunization and auto-antibodies. Ann. intern. Med. 1960, 52, 930.

5. Gajdusek, D. C. An autoimmune reaction against human tissue antigens in certain acute and chronic diseases. I. Serological investigations. A.M.A. Arch. intern. Med. 1958, 101, 9.

6. Kidd, J. G., and Friedewald, W. F. A natural antibody that reacts in vitro with a sedimentable constituent of normal tissue cells. I. Demonstration of the phenomenon. J. exp. Med. 1942, 76, 543.

7. Chaffee, E. E., Fife, E. H., Jr., and Kent, J. F. Diagnosis of Trypanosoma cruzi infection by complement fixation. Amer. J. trop. Med. Hyg. 1956, $5,763$.

8. Bloch, K. J., and Bunim, J. J. Simple, rapid diagnostic test for rheumatoid arthritis-bentonite flocculation test. J. Amer. med. Ass. 1959, 169, 307.

9. Methods for Medical Laboratory Technicians. Bulletin TM8-227. Washington, U. S. Govt. Printing Office, 1951, p. 570.

10. Silverstein, A. M. Essential hypocomplementemia: Report of a case. Blood 1960, 16, 1338.

11. Gear, J. Discussion of tissue specific antibodies in Recent Progress in Microbiology, G. Tunevall, Ed. Stockholm, Almquist and Wiksell, 1959, p. 206.

12. Asherson, G. L. Antibodies against nuclear and cytoplasmic cell constituents in systemic lupus erythematosus and other diseases. Brit. J. exp. Path. 1959, 40, 209.

13. Witebsky, E., Rose, N. R., Terplan, K., Paine, J. R., and Egan, R. W. Chronic thyroiditis and autoimmunization. J. Amer. med. Ass. 1957, 164, 1439.

14. Thal, A. P., Murray, M. J., and Egner, W. Isoantibody formation in chronic pancreatic disease. Lancet 1959, 1, 1128.

15. Broberger, O., and Perlman, P. Autoantibodies in human ulcerative colitis. J. exp. Med. 1959, 110, 657.

16. Lumsden, C. E., Kabat, E. A., Wolf, A., and Bezer, A. E. Studies on acute disseminated encephalomyelitis produced experimentally in Rhesus monkeys. V. Complement-fixing antibodies. J. exp. Med. 1950, 92, 253.

17. Freund, J., Thompson, G. E., and Lipton, M. M. Aspermatogenesis, anaphylaxis, and cutaneous sensitization induced in the guinea pig by homologous testicular extract. J. exp. Med. 1955, 101, 591.

18. Muschel, L. H., Nolte, L. B., and Keiderling, L. J. Some aspects of $\mathrm{Rh}$ antibody determinations. Amer. J. clin. Path. 1957, 27, 42.

19. Holman, H. R. Systemic lupus erythematosusDisease of an unusual immunologic responsiveness? Amer. J. Med. 1959, 27, 525.

20. Deicher, H. R. G., Holman, H. R., and Kunkel, H. Anti-cytoplasmic factors in the sera of patients with systemic lupus erythematosus and certain other diseases. Arth. Rheum. 1960, 3, 1.

21. Kirkham, W. R., and Thomas, L. E. The isolation of globulins from cellular nuclei. J. biol. Chem. 1953, 200, 53.

22. Holman, H. R., Deicher, H. R. G., and Kunkel, H. G. The L.E. cell and the L.E. serum factors. Bull. N. Y. Acad. Med. 1959, 35, 409.

23. Ellis, H. A., and Felix-Davies, D. Serum complement, rheumatoid factor, and other serum proteins in rheumatoid disease and systemic lupus erythematosus. Ann. rheum. Dis. 1959, 18, 215.

24. Miller, J. L., Brodey, M., and Hill, J. H. Studies on significance of biologic false-positive reaction. J. Amer. med. Ass. 1957, 164, 1461.

25. Hackett, E., Beech, M., and Forbes, I. J. Autoimmune complement-fixation reaction in 1,014 patients. Brit. med. J. 1960, 2, 17.

26. Chesney, A. M., and Schipper, G. J. The effect of the method of inoculation upon the course of experimental syphilis in the rabbit. Amer. J. Syph. 1950, 34, 18. 